\title{
Three-year Long Source Apportionment Study of Airborne Particles in Ulaanbaatar Using X-ray Fluorescence and Positive Matrix Factorization
}

\author{
Gerelmaa Gunchin $^{1,2^{*}}$, Manousos Manousakas ${ }^{3}$, Janos Osan ${ }^{2,4}$, Andreas Germanos Karydas ${ }^{5}$, \\ Konstantinos Eleftheriadis $^{3}$, Sereeter Lodoysamba ${ }^{6}$, Dagva Shagjjamba ${ }^{1}$, Alessandro Migliori ${ }^{2}$, \\ Roman Padilla-Alvarez ${ }^{2}$, Christina Streli ${ }^{7}$, Iain Darby ${ }^{2,8}$ \\ ${ }^{1}$ Nuclear Research Center, National University of Mongolia, Ulaanbaatar, Mongolia \\ ${ }^{2}$ Nuclear Science and Instrumentation Laboratory, Physics section, IAEA, Seibersdorf, Austria \\ ${ }^{3}$ Institute of Nuclear \& Radiological Sciences \& Technology, Energy \& Safety, N.C.S.R. Demokritos, Greece \\ ${ }^{4}$ Environmental Physics Department, Hungarian Academy of Sciences Centre for Energy Research, Budapest, Hungary \\ ${ }^{5}$ Institute of Nuclear and Particle Physics, N.C.S.R "Demokritos", Athens, Greece \\ ${ }^{6}$ Faculty of Engineering, German-Mongolian Institute for Resources and Technology, Ulaanbaatar, Mongolia \\ ${ }^{7}$ Vienna University of Technology, Atominstitut, Vienna, Austria \\ ${ }^{8}$ SUPA, School of Physics and Astronomy, University of Glasgow, Glasgow, United Kingdom
}

\begin{abstract}
The capital city of Mongolia, Ulaanbaatar, suffers from high levels of pollution due to excessive airborne particulate matter (APM). A lack of systematic data for the region has inspired investigation into the type, origin and seasonal variations of this pollution, the effects of meteorological conditions and even the time-dependence of anthropogenic sources. This work reports source apportionment results from a large data set of 184 samples each of fine $\left(\mathrm{PM}_{2.5}\right)$ and coarse $\left(\mathrm{PM}_{2.5-10}\right)$ fraction atmospheric PM collected over a three-year period (2014-2016) in Ulaanbaatar, Mongolia. Positive Matrix Factorization (PMF) was applied using the concentrations of 16 elements measured by an energy dispersive X-ray fluorescence spectrometer along with the black carbon content measured by a reflectometer as input data. The PMF results revealed that whereas mixed sources dominate the coarse fraction, soil and traffic sources are the principle contributors to the fine fraction. The source profiles and the seasonal variations of their contributions indicate that fly ash emanating from coal combustion mixes with traffic emissions and resuspended soil, resulting in variable chemical source profiles. Four sources were identified for both fractions, namely, soil, coal combustion, traffic and oil combustion, which respectively contributed $35 \%, 16 \%, 41 \%$ and $8 \%$ to the coarse fraction and $31 \%, 27 \%, 31 \%$ and $11 \%$ to the fine fraction. Additionally, the probable source contributions from long-range transport events were assessed via concentration-weighted trajectory analysis.
\end{abstract}

Keywords: Airborne particulate matter; XRF; PMF; Ulaanbaatar.

\section{INTRODUCTION}

Atmospheric pollution due to particulate matter (PM) is a wide concern for both human health and the climate (Cohen et al., 2004; Ostro et al., 2015). Aerosol particles can be formed either from precursor gases via chemical reactions in the atmosphere or be directly emitted from various sources of anthropogenic and natural origin (Davy et al., 2011). PM is a mixture of organic and inorganic compounds and it is important to be able to identify its

\footnotetext{
* Corresponding author.

E-mail address: gerelmaa-g@num.edu.mn
}

sources and quantify their contributions (Hasenkopf et al., 2016; Diapouli et al., 2017).

The process of identification and apportionment of pollutants to their sources is an important step in air quality management, since this can be used as baseline data for the establishment of air pollution mitigation strategies. Multivariate receptor models are very useful tools as they may be applied directly to the observed PM composition data (Santoso et al., 2008). The dataset of the PM elemental composition is an essential input for the characterization of specific emission sources using statistical apportionment tools such as the Positive Matrix Factorization (PMF) model (Paatero et al., 2003), and can be accompanied by complementary data (e.g., black carbon, organic carbon, water-soluble ions). Generally, major 
elements such as $\mathrm{Mg}, \mathrm{Al}, \mathrm{Si}, \mathrm{Ca}, \mathrm{Ti}$ and $\mathrm{Fe}$ are primarily associated with windblown soil, $\mathrm{S}$ with fossil fuel burning, and $\mathrm{K}$ with smoke and biomass burning, whereas $\mathrm{Cr}, \mathrm{Mn}$, $\mathrm{Fe}, \mathrm{Cu}$ and $\mathrm{Zn}$ are associated with industrial processes, while $\mathrm{Pb}$ and $\mathrm{Br}$ derive from motor vehicle exhaust (Cohen et al., 2014; Manousakas et al., 2015). For a comprehensive source apportionment, a group of analytical techniques should be applied to determine the concentration of the maximum number of elements being either major, minor or trace constituents of the PM mass. Importantly, the respective uncertainties for the elemental concentrations should be well defined for source apportionment studies, as they are used in the model.

$\mathrm{X}$-ray fluorescence (XRF) analysis is a multi-elemental, sensitive and very versatile analytical method widely used in various scientific fields and amongst the ones best suited for environmental researches and particularly for PM analyses (Calzolai et al., 2008; Shaltout et al., 2017; Prost et al., 2018). In this study, an energy-dispersive XRF spectrometer (Epsilon 5; PANalytical, Inc., Almelo, the Netherlands) was used for the elemental analysis. The combined result of employing several secondary targets, coupled within a three-dimensional polarizing optical geometry, leads to the significant reduction in the measured PM XRF spectrum of the scattered X-rays from the tube emission, thus lowering the continuum counts (noise signal). Such a reduction of the noise signal, in combination with the instrument sensitivity gains achieved by optimizing the excitation conditions for different groups of elements, enables obtaining minimum detection limits in the low $\mathrm{ng} \mathrm{\textrm {cm } ^ { - 2 }}$ range or even below for most of the elements of interest (Shaltout et al., 2018). For the determination of black carbon (BC) content, an M43D smoke stain reflectometer from Diffusion Systems Ltd. (London, United Kingdom) was used.

Herein we present source apportionment results from a large data set of fine $\left(\mathrm{PM}_{2.5}\right)$ and coarse $\left(\mathrm{PM}_{2.5-10}\right)$ fraction atmospheric PM samples collected over a three-year period (2014-2016) in Ulaanbaatar, Mongolia.

\section{METHODS}

\section{Sample Collection}

Mongolia is located across northeast and central Asia at an average altitude of $1400 \mathrm{~m}$ above sea level. Its elevation, relatively high latitude, non-coastal geography and the effects of Siberian anticyclone weather patterns give the country a continental dry climate with long, cold winters and relatively short summers. Average temperatures from November to March drop below $0^{\circ} \mathrm{C}$ over the whole country. The capital and largest city, Ulaanbaatar, is located on Tuul River Valley and surrounded by mountains. The total area of the city is $4735.1 \mathrm{~km}^{2}$ and has approximately 1.4 million inhabitants, comprising $45 \%$ of the whole country's population. According to a recent report (Ulaanbaatar City Governor's Implementation Agency, 2016), 43.3\% of Ulaanbaatar residents live in apartment buildings which are connected to the main central heating grid and the remaining $56.7 \%$ of inhabitants live in traditional Mongolian dwelling areas, called ger khoroolol, where coal, wood and other household materials are used as fuel for domestic heating and cooking purposes. The annual consumption statistics of coal and wood for Ulaanbaatar inhabitants are described elsewhere (Guttikunda, 2007). The regional climate, geographical location and residential features of Ulaanbaatar city intensify a winter air pollution problem. It is for these reasons that Ulaanbaatar is reported as one of the world's most polluted cities (World Bank, 2011).

A total of 184 air particulate matter samples, sizefractionated according to aerodynamic diameter between 10 microns and 2.5 microns ( $\mathrm{PM}_{10-2.5}$, or coarse fraction) and 2.5 microns or less $\left(\mathrm{PM}_{2.5}\right.$, or fine fraction), were collected for two days per week (Monday and Thursday) throughout the period 2014-2016. The sampling site was located at the Nuclear Research Center (NRC) of the National University of Mongolia (NUM) (Fig. 1). The monitoring site is surrounded by a combination of buildings, ger khoroolol, paved and unpaved roads.

Sampling was undertaken using a GENT instrument (Maenhaut et al., 1993), comprising a $\mathrm{PM}_{10}$ impactor-type size-selective inlet and a stacked filter unit (SFU) assembly connected to a pump and an air flow meter. The SFU is made up of two filters arranged sequentially. The upper filter (with $8-\mu \mathrm{m}$ pore size, type polycarbonate) collects the coarse fraction, and the lower filter (with $0.4-\mu \mathrm{m}$ pore size, type polycarbonate) collects the fine fraction. The average air flow rate was $16.0 \mathrm{~L} \mathrm{~min}^{-1}$ and the average mass loadings for $\mathrm{PM}_{2.5}$ and $\mathrm{PM}_{10-2.5}$ were $92 \mu \mathrm{g} \mathrm{m}^{-3}$ and $131 \mu \mathrm{g} \mathrm{m}^{-3}$, respectively. The collection of the samples covered a 24 -hour period. However, on winter days it was not possible to collect over the entire 24 hours as high pollution resulted in clogging of the filters. Therefore, the sampler was operated during alternating on and off periods over the course of the 24 hours so as to provide a representative sample for that day.

Gravimetric masses of the samples were obtained in triplicate measurements using a digital weighing balance that has an automatic calibration function to ensure accuracy. Gravimetric masses were subsequently divided by the sampled air volume to calculate average PM mass concentrations.

The black carbon (BC) measurement and its quantification model are described elsewhere (Davy et al., 2011).

\section{Elemental Analysis, XRF}

$\mathrm{XRF}$ analysis has been performed in the IAEA Nuclear Science and Instrumentation Laboratory (NSIL) in Seibersdorf, Austria. The spectrometer features a variety of secondary targets, such as $\mathrm{Al}, \mathrm{CaF}_{2}, \mathrm{Fe}, \mathrm{Ge}, \mathrm{Zr}, \mathrm{Mo}, \mathrm{Ag}$ and $\mathrm{Al}_{2} \mathrm{O}_{3}$ (Barkla polarization target) which are excited by an $\mathrm{Sc}-\mathrm{W}$ tube. The characteristic X-ray radiation emitted by the sample is detected by a Ge detector with a measured energy resolution of approximately $150 \mathrm{eV}$ FWHM at $\mathrm{Mn}-\mathrm{K} \alpha(5.89 \mathrm{keV})$. Eight measuring conditions were selected to optimize the analytical sensitivity and precision for the determination of certain groups of elements in aerosol particles on filters as presented in Table 1. For all secondary and polarization targets, the live time of the measurements was set to 300 seconds. The analysis was performed in vacuum. 


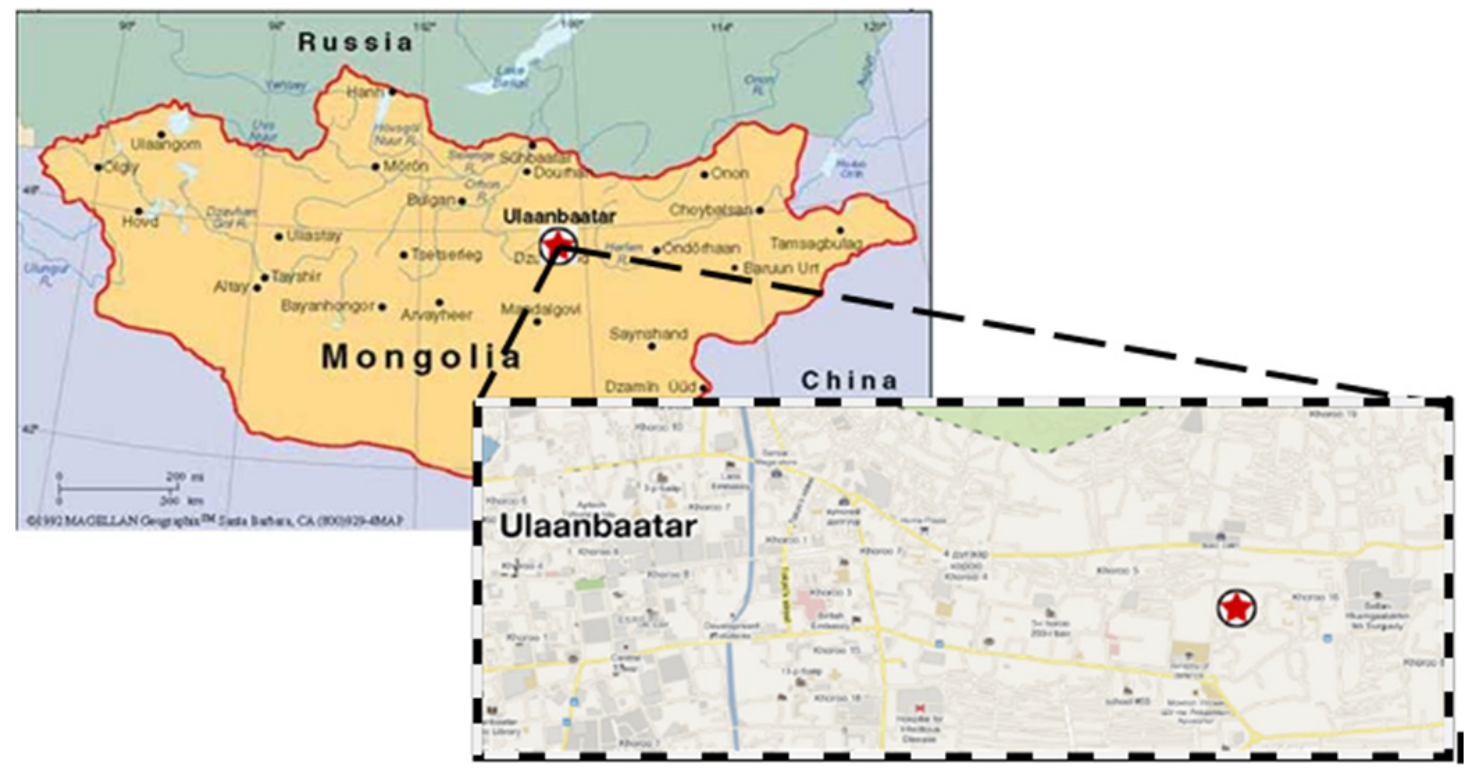

Fig. 1. Nuclear Research Center (NRC) air quality monitoring site, 4 kilometers east of the center of Ulaanbaatar (latitude: 4755', longitude: $106^{\circ} 55^{\prime}, 1300 \mathrm{~m}$ above sea level). Source: (C)1992 MAGELLAN Geographix ${ }^{\mathrm{TM}}$ and https://maps.google.com/.

Table 1. XRF spectrometer (PANalytical Epsilon 5) conditions for elemental analysis of APM.

\begin{tabular}{lllll}
\hline Nr. & Targets & Detected elements & Voltage (kV) & Current (mA) \\
\hline 1 & $\mathrm{Al}$ & $\mathrm{Na}, \mathrm{Mg}$ & 25 & 24 \\
2 & $\mathrm{CaF} 2$ & $\mathrm{Al}, \mathrm{Si}, \mathrm{P}, \mathrm{S}, \mathrm{Cl}, \mathrm{K}$ & 40 & 15 \\
3 & $\mathrm{Fe}$ & $\mathrm{Ca}, \mathrm{Sc}, \mathrm{Ti}, \mathrm{V}, \mathrm{Cr}$ & 75 & 8 \\
4 & $\mathrm{Ge}$ & $\mathrm{Mn}, \mathrm{Fe}, \mathrm{Co}, \mathrm{Ni}, \mathrm{Cu}, \mathrm{Zn}$ & 75 & 8 \\
5 & $\mathrm{Zr}$ & $\mathrm{Ga}, \mathrm{Ge}, \mathrm{As}, \mathrm{Se}, \mathrm{Br}, \mathrm{Pb}-\mathrm{L}$ & 100 & 6 \\
6 & $\mathrm{Mo}$ & $\mathrm{Sr}, \mathrm{Y}$ & 100 & 6 \\
7 & $\mathrm{Ag}$ & $\mathrm{Zr}, \mathrm{Nb}, \mathrm{Mo}, \mathrm{Tc}, \mathrm{Ru}$ & 100 & 6 \\
8 & $\mathrm{Al}_{2} \mathrm{O}_{3}$ & $\mathrm{Rh}, \mathrm{Pd}, \mathrm{Ag}, \mathrm{Cd}, \mathrm{In}, \mathrm{Sn}, \mathrm{Sb}, \mathrm{Te}, \mathrm{I}, \mathrm{Cs}, \mathrm{Ba}, \mathrm{La}, \mathrm{Ce}$ & 100 & 6 \\
\hline
\end{tabular}

The quantification was based on a calibration performed by measuring thin film single element and compound reference materials (Micromatter, Surrey, BC, Canada), prepared on a polycarbonate filter support. The nominal areal densities of the certified materials ranged between $43.8 \mu \mathrm{g} \mathrm{cm}^{-2}$ and $62.3 \mu \mathrm{g} \mathrm{cm}^{-2}$ with relative uncertainties quoted as $5 \%$. The following standards were used for calibration purposes: $\mathrm{NaCl}, \mathrm{MgF}_{2}, \mathrm{Al}, \mathrm{SiO}, \mathrm{KCl}, \mathrm{CaF}_{2}, \mathrm{Ti}$, $\mathrm{V}, \mathrm{Mn}, \mathrm{Fe}, \mathrm{Co}, \mathrm{Ni}, \mathrm{Cu}, \mathrm{ZnTe}, \mathrm{Nb}_{2} \mathrm{O}_{3}, \mathrm{MoO}_{3}, \mathrm{CdSe}, \mathrm{Sn}, \mathrm{Sb}$, $\mathrm{BaF}_{2}, \mathrm{CeF}_{3}, \mathrm{NdF}_{3}, \mathrm{HoF}_{3}, \mathrm{YbF}_{3}, \mathrm{WO}_{3}, \mathrm{Au}, \mathrm{TlCl}$ and $\mathrm{Pb} . \mathrm{A}$ Standard Reference Material of particulate matter on filter media (SRM 2783; NIST, Gaithersburg, MD, USA) was used for validation of the analytical method. The provided software of the Epsilon 5 was used for spectrum deconvolution, whereas the elemental concentrations were calculated using a sensitivity curve determined by the available set of thin single- or two-element standards.

For the estimation of the combined uncertainty of the results, the following contributing factors were considered: the peak area statistical uncertainty, the fitting error in the calibration (sensitivity) curve, the quoted uncertainties of the elemental areal densities reported for the standards $(5 \%)$, the estimated error due to the omittance of the selfattenuation effect for the excitation and detection of light- element characteristic X-rays (the calibration was based on presuming the samples as infinitely thin in the sense of $\mathrm{X}$-ray attenuation), as well as the relative standard deviation of three replicate measurements (reproducibility in operation). The self-attenuation effect occurs significantly within the PM sample components due to the low energy of the exciting and characteristic X-rays used in the measurement of light elements. According to a previous study (Gutknecht et al., 2010), the bias of results due to the omittance of self-attenuation correction is estimated to be $16 \%$ for $\mathrm{Na}$, $12 \%$ for $\mathrm{Mg}$ and $11 \%$ for $\mathrm{Al}$ and $\mathrm{Si}$, whereas for the rest of measured elements is considered as $1 \%$. The measurement's precision was calculated as the standard deviation of results from three consecutive measurements for twenty representative samples. Finally, the combined relative uncertainty is calculated as the square root of the sum of squares of the various contributing relative uncertainties (Gutknecht et al., 2010; Manousakas et al., 2017).

The elemental minimum detection limits (MDLs) were obtained by measuring the National Institute for Standards and Technology (NIST) Standard Reference Material (SRM) 2783. In Fig. 2, the MDLs of the measured elements are presented for a measurement time of $300 \mathrm{~s}$ and the employed secondary target for each element is denoted by 


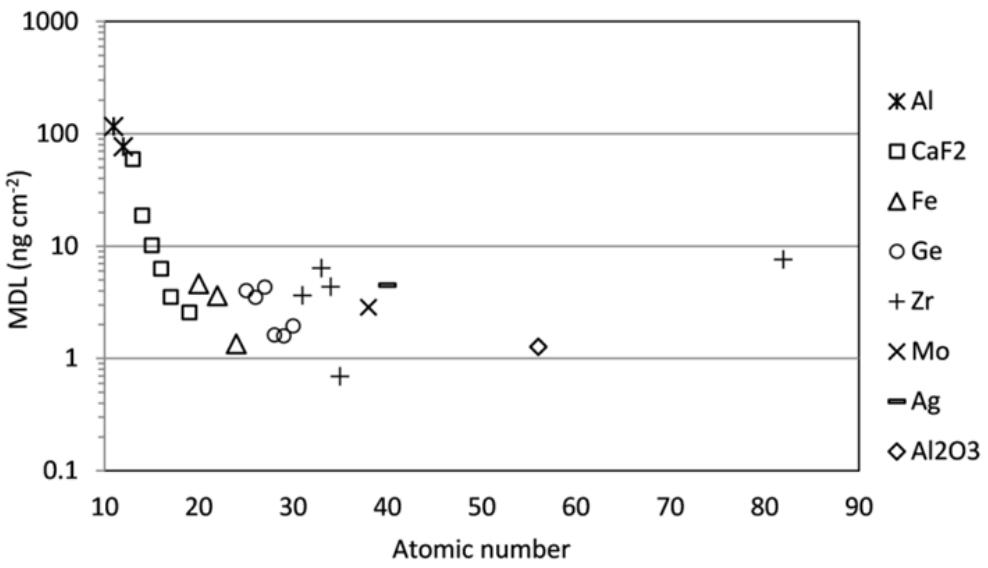

Fig. 2. Minimum detection limit values established from the NIST reference material (SRM 2783) air particulate filter.

different symbols. The detection limits were calculated taking three times the square root of background counts (measured continuum under the characteristic peak) as the minimum detectable peak area.

\section{Positive Matrix Factorization}

U.S. EPA Positive Matrix Factorization (PMF) (Paatero, 1997) 5.0 was used for the source identification and apportionment of both the $\mathrm{PM}_{2.5}$ and $\mathrm{PM}_{10-2.5}$ fractions. Fifteen species of $\mathrm{PM}_{10-2.5}$ (BC, Na, Mg, Al, Si, S, Cl, K, Ca, $\mathrm{Ti}, \mathrm{Mn}, \mathrm{Fe}, \mathrm{Zn}, \mathrm{Pb}$ and Mass) and twelve species of $\mathrm{PM}_{2.5}$ (BC, Al, Si, S, K, Ca, Ti, Mn, Fe, Zn, Pb and Mass) were used for the PMF modeling. $\mathrm{Na}, \mathrm{Mg}$, and $\mathrm{Cl}$ were considered as "weak" or "bad" depending on the uncertainties that were associated with their measurement.

The basic equation that refers to the solution of the mass balance problem is common for all receptor models including PMF. The equation can be written as Eq. (1):

$\mathrm{X}=\mathrm{G} \times \mathrm{F}+\mathrm{E}$

where $\mathrm{X}$ is the concentration of species measured on sample, $G$ is the contribution of the source, $F$ the source profile and $\mathrm{E}$ the residual. Since the PMF solution is not unique, to obtain the optimum solution $\mathrm{G}$ and $\mathrm{F}$ are adjusted until a minimum $Q$ for a given number of factors is found. $Q$ is defined as Eq. (2):

$$
Q=\sum_{j=1}^{m} \sum_{i=1}^{n} \frac{E_{i j}^{2}}{S_{i j}^{2}}
$$

where $s_{i j}$ is the uncertainty of the $j^{\text {th }}$ species concentration in sample $i, n$ is the number of samples, and $m$ is the number of species.

Solutions with a number of factors from 3 to 8 were investigated in order to identify the meaningful solution with the highest number of factors. For both PM fractions the optimum solution was found to be for 4 factors. Data were screened by their uncertainties (signal-to-noise ratio $(\mathrm{S} / \mathrm{N})$ in $\mathrm{PMF})$. Variables with very low $\mathrm{S} / \mathrm{N}$ ratios $(\leq 0.2)$ were defined to be bad and excluded from the analysis, while weak variables $(0.2 \leq \mathrm{S} / \mathrm{N} \leq 2)$ were down-weighted (Paatero and Hopke, 2003). For $\mathrm{PM}_{2.5}$ analysis, the elements $\mathrm{Na}, \mathrm{Mg}$ and $\mathrm{Cl}$ were excluded; $\mathrm{V}$ and $\mathrm{Cr}$ were defined as "bad" and $\mathrm{BC}, \mathrm{Cu}, \mathrm{Zn}, \mathrm{Pb}$ and As were defined as "weak" variables and for $\mathrm{PM}_{10-2.5}$ analysis only $\mathrm{Cr}$ was defined as "bad" and $\mathrm{BC}, \mathrm{Na}, \mathrm{Mg}, \mathrm{Cl}, \mathrm{Ni}, \mathrm{Zn}, \mathrm{Pb}$ and As species were defined as "weak". The mass was set as total variable for analyses. The robustness of the solutions was investigated using the uncertainty estimation tool that EPA PMF 5.0 offers. According to bootstrap analysis (Reff et al., 2007) the factors were reproduced at a level higher that $80 \%$, while no factor swaps appeared for the minimum level of $Q$ at displacement and bootstrap displacement analysis. The comparison between predicted (PMF) and gravimetric masses of both the fractions were found to be high $\left(\mathrm{R}_{\text {coarse }}^{2}=0.82\right.$ and $\mathrm{R}_{\text {fine }}^{2}=0.86$ ).

\section{RESULTS}

\section{Particulate Matter Concentrations}

The average concentrations of annual and seasonal coarse and fine particulates are shown in Tables 2 and 4. The presented values indicated that annual concentrations of both the fractions are much higher than Mongolian National Ambient Air Quality Standards (MNS 4585:2007), set to yearly averages of $50 \mu \mathrm{g} \mathrm{m}^{-3}$ for $\mathrm{PM}_{10}$ and $25 \mu \mathrm{g} \mathrm{m}^{-3}$ for $\mathrm{PM}_{2.5}$, as well as the World Health Organization (WHO)'s guideline (WHO, 2005) corresponding values of $20 \mu \mathrm{g} \mathrm{m}^{-3}$ and $10 \mu \mathrm{g} \mathrm{m}^{-3}$. $\mathrm{PM}_{10}$ limit values are used in the text not for direct comparison but as reference to provide a better metric regarding the measured mass concentration levels. Particulate matter concentrations were dominated by the coarse fraction for the whole study period. The maximum concentrations were measured at $580 \mu \mathrm{g} \mathrm{m}^{-3}$ for the coarse particle and $7 \%$ of the total sampling days were above $300 \mu \mathrm{g} \mathrm{m}^{-3}$, and the annual and seasonal values show that no drastic difference between warm (April-September) and cold (October-March) season averages exist (Fig. 3). The fine particle concentration increases during the cold season and highest values were recorded during winter months while the concentration went often over $100 \mu \mathrm{g} \mathrm{m}^{-3}$. 


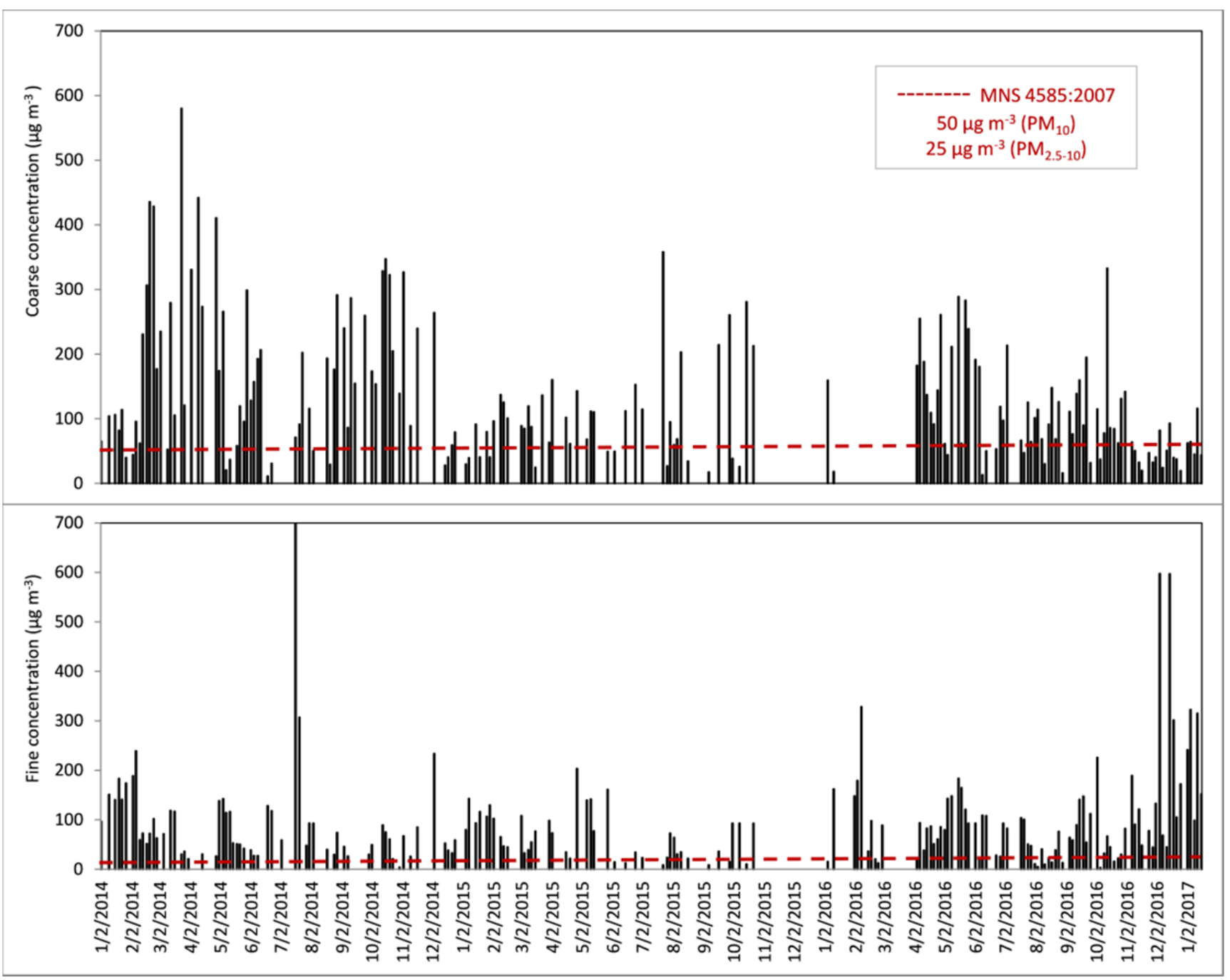

Fig. 3. Time series of both $\mathrm{PM}_{10-2.5}$ (upper) and $\mathrm{PM}_{2.5}$ (lower) fractions at the sampling site, from January 2014 to January 2017.

\section{PMF Analysis Results}

$P M_{10-2.5}$ Data Analysis

In Table 2, the descriptive statistics regarding $\mathrm{PM}_{10-2.5}$ and elemental mass concentrations are presented. The minimum detection limits (MDLs), number of elemental constituents which were detected above their respective MDLs, as well as average elemental concentrations during warm and cold season are also included in the table.

As presented in Table 2, for the coarse fraction the elements $\mathrm{Al}, \mathrm{Si}, \mathrm{Ca}, \mathrm{Ti}$ and $\mathrm{Fe}$ originate mainly from a crustal matter source and were higher in the warm period. The Si:Al ratio was found to be 2.6, indicative of a typical soil composition - aluminosilicates (Lide, 1992).

Several Factors (3-8) were used in order to obtain the optimum PMF solution, and settling upon 4 contributing factors to be the solution was chosen with regard to the highest number of factors with physical sense. The factors have been identified based on the key elements in the source fingerprint and the correlations between them. The selected sources are traffic, soil, coal combustion and oil and their elemental profiles are presented in Fig. 4.
The first profile has been identified as traffic, although elemental profile shows that this factor can be a combination of several combustion sources as it contains the highest percentage of $\mathrm{BC}$ and $\mathrm{S}$, as well as elements with crustal and anthropogenic origin. However, the high percentage of elements such as $\mathrm{Ni}, \mathrm{Cu}, \mathrm{Zn}$ and $\mathrm{Pb}$ indicates that this factor mainly represents a traffic source (Sarigiannis et al., 2017). This source contributes $41 \%$ of the total $\mathrm{PM}_{10-2.5}$ mass and seasonal variation presents higher contribution in the cold season. The fact that the source has higher contribution during the cold season is another indication that the source is mixed with other combustion sources such as coal, which is used for residential heating and is expected to have a higher contribution during the cold season.

The second source profile was identified as soil since it contains crustal matter elements $\mathrm{Mg}, \mathrm{Al}, \mathrm{Si}, \mathrm{Ca}, \mathrm{Ti}, \mathrm{Mn}$ and $\mathrm{Fe}$. Moreover, this factor has high presence of $\mathrm{Na}, \mathrm{Cl}$, $\mathrm{K}$ and $\mathrm{Zn}$ which indicates that it might be mixed with some other sources such as salt and anthropogenic sources that can contribute to this source by soil resuspension (Eleftheriadis and Colbeck, 2001). The contribution of this source is $35 \%$ 
Table 2. Summary statistics for $\mathrm{PM}_{10-2.5}, \mathrm{BC}$ and elemental concentrations.

\begin{tabular}{lllllllll}
\hline $\mathrm{ng} \mathrm{m}^{-3}$ & Average & S.D & Median & Max. & Min. & \# Samples > MDL & Warm & Cold \\
\hline $\mathrm{Mass}$ & 131000 & 102000 & 101000 & 579000 & 10800 & 183 & 136000 & 123000 \\
$\mathrm{BC}$ & 3850 & 2130 & 3800 & 11300 & 372 & 182 & 3430 & 4870 \\
$\mathrm{Na}$ & 708 & 394 & 625 & 3260 & 142 & 183 & 689 & 750 \\
$\mathrm{Mg}$ & 604 & 325 & 549 & 1770 & 126 & 176 & 616 & 592 \\
$\mathrm{Al}$ & 4660 & 3400 & 4000 & 15000 & 376 & 183 & 5140 & 4030 \\
$\mathrm{Si}$ & 12500 & 9340 & 10900 & 40700 & 855 & 183 & 13900 & 10600 \\
$\mathrm{~S}$ & 1000 & 913 & 662 & 4560 & 57.0 & 183 & 708 & 1600 \\
$\mathrm{Cl}$ & 338 & 280 & 266 & 1960 & 34.0 & 183 & 334 & 327 \\
$\mathrm{~K}$ & 1830 & 1390 & 1550 & 6170 & 124 & 183 & 2040 & 1540 \\
$\mathrm{Ca}$ & 4270 & 2800 & 3580 & 15000 & 494 & 183 & 4510 & 3910 \\
$\mathrm{Ti}$ & 368 & 264 & 322 & 1190 & 32.0 & 183 & 406 & 314 \\
$\mathrm{~V}$ & 5.00 & 4.00 & 4.00 & 17.0 & 5.00 & 161 & 5.00 & 4.00 \\
$\mathrm{Cr}$ & 7.00 & 4.00 & 7.00 & 23.0 & 2.00 & 183 & 7.00 & 8.00 \\
$\mathrm{Mn}$ & 99.0 & 67.0 & 84.0 & 318 & 10.0 & 183 & 107 & 91.0 \\
$\mathrm{Fe}$ & 3930 & 2840 & 3250 & 13200 & 316 & 183 & 4280 & 3450 \\
$\mathrm{Ni}$ & 4.00 & 2.00 & 4.00 & 16.0 & 2.00 & 182 & 4.00 & 4.00 \\
$\mathrm{Cu}$ & 18.0 & 9.0 & 16.0 & 74.0 & 5.00 & 183 & 17.0 & 19.0 \\
$\mathrm{Zn}$ & 62.0 & 46.0 & 52.0 & 271 & 5.00 & 183 & 60.0 & 69.0 \\
$\mathrm{~Pb}$ & 29.0 & 28.0 & 23.0 & 316 & 8.00 & 183 & 24.0 & 37.0 \\
$\mathrm{As}$ & 8.00 & 8.00 & 6.00 & 46.0 & 6.00 & 130 & 7.00 & 11.0 \\
\hline
\end{tabular}

of the total $\mathrm{PM}_{10-2.5}$ mass. Seasonal variations indicated that this source has a higher contribution during the warm period (Fig. 5).

The third source profile, coal combustion, is traced by the high concentration of $\mathrm{BC}$ and $\mathrm{S}$. It is not very common that a combustion source affects the coarse PM fraction to that extent. A possible explanation for this can be that as the ashes which remain in the stove after the burning of coal for domestic heating are in many cases discarded by the populace on the soil, the ashes may then become resuspended along with soil and other anthropogenic related elements. The contribution of this source is $16 \%$.

The last factor was identified as oil combustion as it contains a significant amount of $\mathrm{V}$ and $\mathrm{Ni}$. Interestingly, this source is for the first time identified on this site. In previous studies conducted in the area (Davy et al., 2011; Gunchin et al., 2012) this source profile was not found. This source has a contribution of $8 \%$ of the total mass and presents low temporal variation.

The output of PMF was used to calculate the annual contribution of the sources for the three years of the study. Table 3 presents average mass contributions of the sources to the $\mathrm{PM}_{10-2.5}$ fraction for each year. The results of Table 3 reveal that the sources of the coarse fraction appear to be stable for the three years of the study period. However, the average mass of the year 2015 was relatively low when compared with that of the years 2014 and 2016. This might be affected by the missing data of November and December 2015. As it is presented in Table 3, the variance in the source contributions for the three years the study was conducted is low.

\section{$\mathrm{PM}_{2.5}$ Data Analysis}

Table 4 presents $\mathrm{PM}_{2.5}$ descriptive statistics. The minimum detection limits (MDLs), number of elemental constituents which were detected above their respective MDLs and average concentrations during warm and cold season are also included in Table 4. As presented in Table 4, BC, S, $\mathrm{Zn}$ and As species significantly dominate the fine fraction. The average concentrations were much higher in cold periods compared to warm seasons. The correlation of BC and $\mathrm{S}$ components was 0.96 , clearly indicating that they have a common source which is likely coal combustion.

Based on the key contribution of certain elements, the number of sources that were identified for the fine fraction was 4 as well. These are soil, traffic, coal combustion and oil. The elemental source profiles are presented in Fig. 6.

The elemental profile of soil includes clear contribution of crustal matter elements such as $\mathrm{Mg}, \mathrm{Al}, \mathrm{Si}, \mathrm{Ca}, \mathrm{Ti}, \mathrm{Mn}$ and $\mathrm{Fe}$. The correlation of the concentrations of $\mathrm{Al}$ and $\mathrm{Si}$ was 0.96 which indicates typical soil origin. The contribution of this source is $31 \%$ of the total $\mathrm{PM}_{2.5}$ mass and it is slightly higher during the warm period than the annual average (Fig. 7).

The second source profile is identified as traffic. Higher percentage of elements such as $\mathrm{Ni}, \mathrm{Cu}, \mathrm{Zn}$ and $\mathrm{Pb}$ in this profile indicates that this factor mainly from traffic. This source has a contribution of $31 \%$ of the total $\mathrm{PM}_{2.5}$ mass. However, this source profile also includes a high presence of $\mathrm{BC}$ and this might influence the total contribution of this source. Seasonal variance shows this factor has higher contribution during the cold season.

The third source has been identified as coal combustion since it is characterized by significantly higher concentrations of $\mathrm{BC}$ and $\mathrm{S}$. The correlation of these two components was 0.90. This factor represented $27 \%$ of the total $\mathrm{PM}_{2.5}$ mass. Interestingly, contribution of this source was lower than crustal matter source in a fine fraction. However, this factor also containing different source elements such as $\mathrm{V}, \mathrm{Zn}$ and $\mathrm{Pb}$ which indicates that the factors is slightly mixed 
Traffic (C)

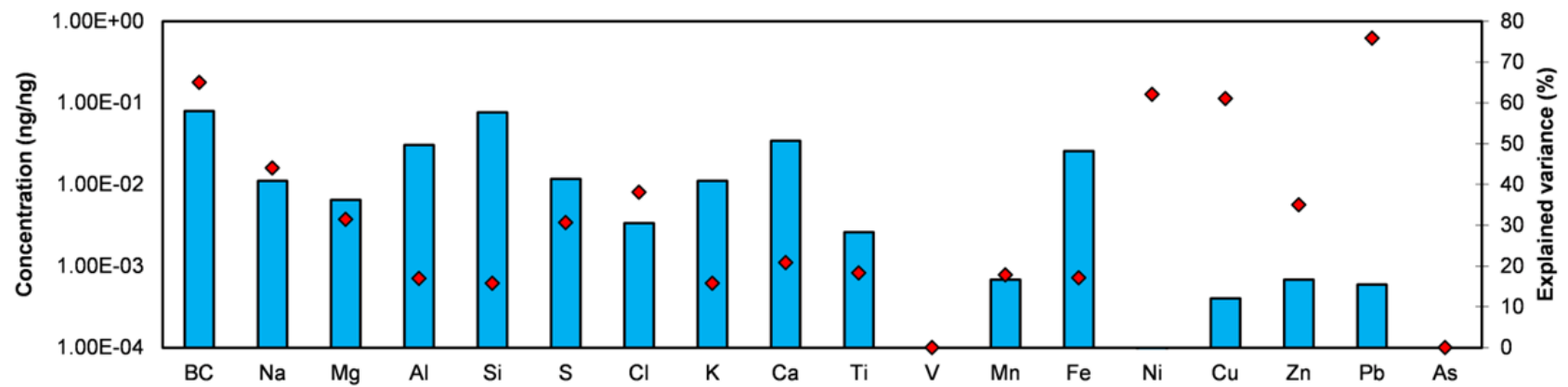

Soil (C)

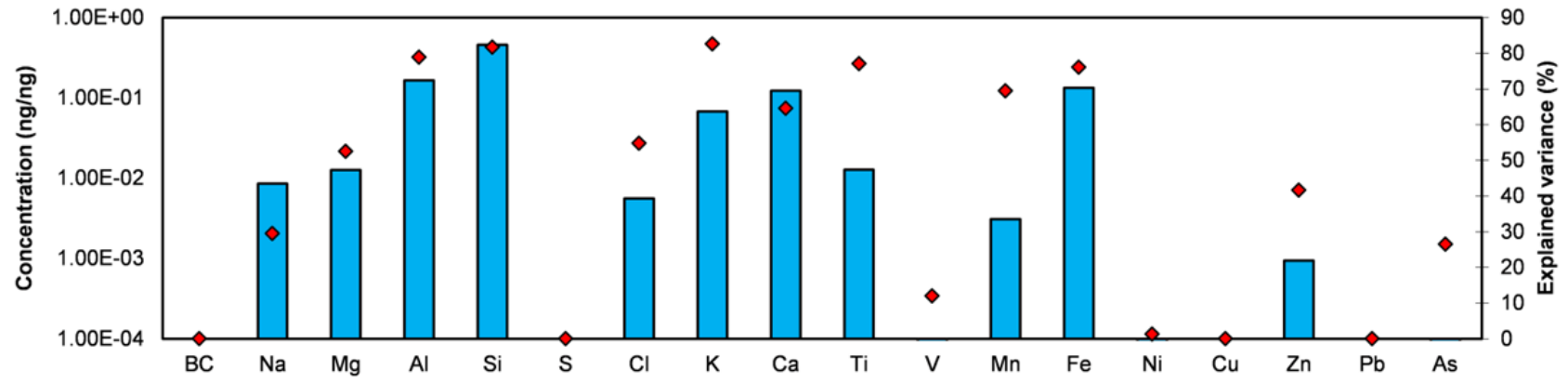

Coal combustion (C)

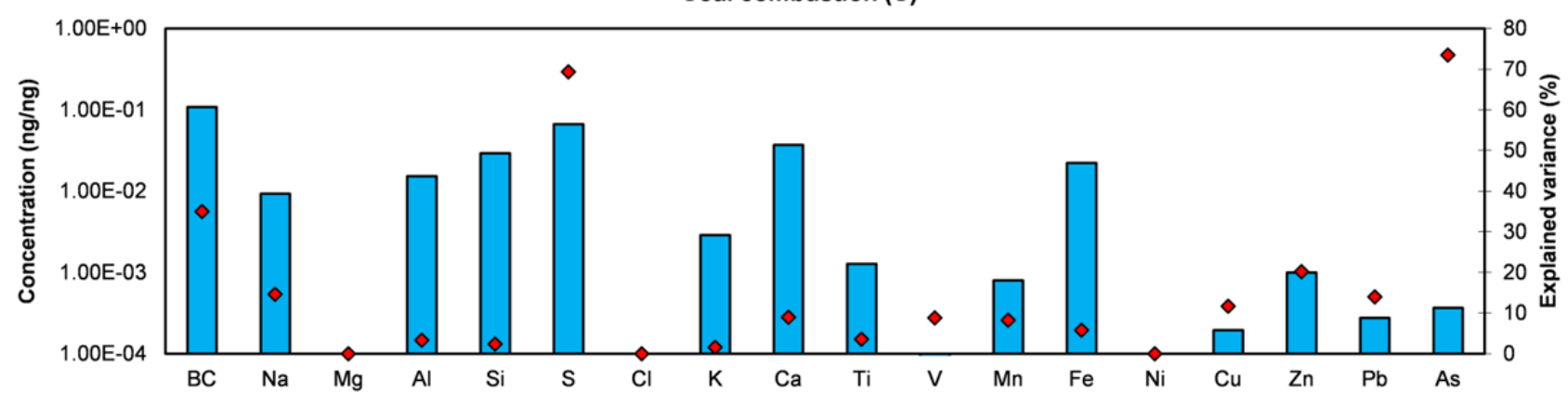

Oil (C)

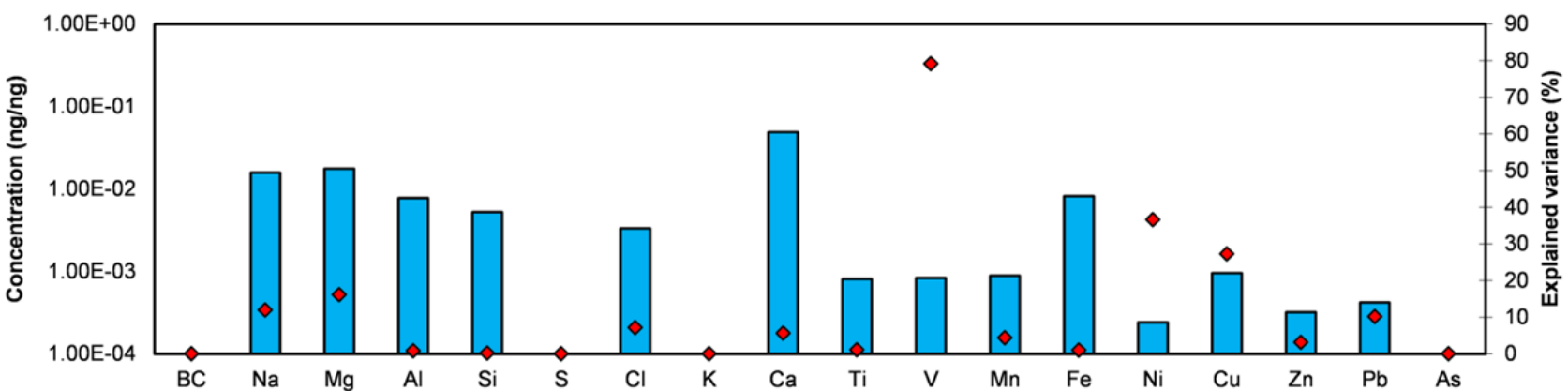

Fig. 4. Elemental source profiles derived by PMF for $\mathrm{PM}_{10-2.5}$ samples.

with traffic and road dust. Additionally, As appears in this source profile in relatively enhanced concentration. The same feature applies to coal combustion source in the coarse fraction as well. It should be noted that As is a known tracer of coal combustion.

The last factor identified as oil presents the very similar source profile as the coarse fraction, and has a significant amount of $\mathrm{V}$ and $\mathrm{Ni}$. A contribution of this source has $11 \%$ of the total mass and has higher seasonal trend during the cold months.

The annual contributions were calculated for the fine fraction as well. Table 5 presents average mass contributions of each year of the $\mathrm{PM}_{2.5}$ sources. It seems that in 2016 the coal combustion source was increased by $13-15 \%$, whereas 


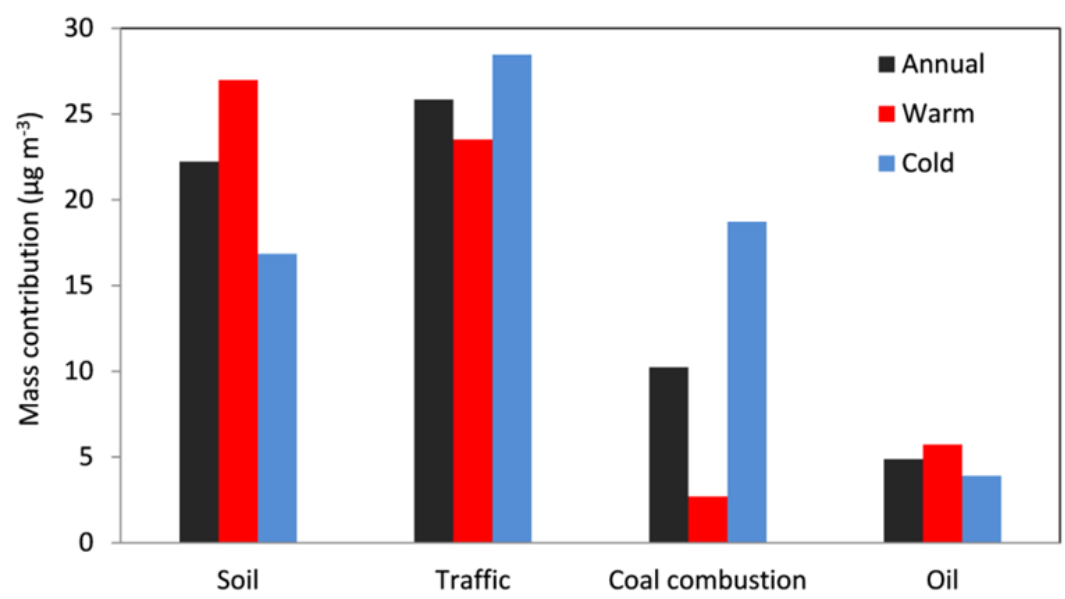

Fig. 5. Seasonal source mass contribution to $\mathrm{PM}_{10-2.5}$.

Table 3. Yearly source contributions to $\mathrm{PM}_{10-2.5}$.

\begin{tabular}{|c|c|c|c|c|c|c|}
\hline \multirow{2}{*}{ Sources } & \multicolumn{2}{|l|}{2014} & \multicolumn{2}{|l|}{2015} & \multicolumn{2}{|l|}{2016} \\
\hline & Average $\left(\mu \mathrm{g} \mathrm{m}^{-3}\right)$ & $\%$ & Average $\left(\mu \mathrm{g} \mathrm{m}^{-3}\right)$ & $\%$ & Average $\left(\mu \mathrm{g} \mathrm{m}^{-3}\right)$ & $\%$ \\
\hline Traffic & 28 & 42 & 14 & 37 & 25 & 43 \\
\hline Soil & 24 & 36 & 12 & 39 & 19 & 32 \\
\hline Coal combustion & 10 & 15 & 5 & 17 & 10 & 17 \\
\hline Oil & 5 & 8 & 3 & 8 & 5 & 8 \\
\hline
\end{tabular}

Table 4. Summary statistics for $\mathrm{PM}_{2.5}, \mathrm{BC}$ and elemental concentrations.

\begin{tabular}{lllllllll}
\hline $\mathrm{ng} \mathrm{m}^{-3}$ & Average & S.D & Median & Max. & Min. & \# Samples > MDL & Warm & Cold \\
\hline $\mathrm{Mass}$ & 92800 & 95200 & 72700 & 70000 & 2770 & 184 & 77300 & 10800 \\
$\mathrm{BC}$ & 6590 & 6340 & 4260 & 50900 & 1030 & 184 & 3120 & 10100 \\
$\mathrm{Na}$ & 391 & 210 & 331 & 1900 & 69.0 & 184 & 304 & 478 \\
$\mathrm{Mg}$ & 251 & 178 & 218 & 1600 & 91.0 & 157 & 210 & 299 \\
$\mathrm{Al}$ & 737 & 470 & 588 & 2292 & 133 & 184 & 739 & 736 \\
$\mathrm{Si}$ & 1490 & 1110 & 1130 & 5570 & 141 & 184 & 1550 & 1430 \\
$\mathrm{~S}$ & 1740 & 2600 & 684 & 20600 & 119 & 184 & 458 & 30490 \\
$\mathrm{Cl}$ & 43.0 & 69.0 & 28.0 & 817 & 5.00 & 182 & 30.0 & 56.0 \\
$\mathrm{~K}$ & 259 & 155 & 214 & 946 & 23 & 184 & 241 & 276 \\
$\mathrm{Ca}$ & 567 & 390 & 449 & 2690 & 50.0 & 184 & 511 & 626 \\
$\mathrm{Ti}$ & 38.0 & 28.0 & 30.0 & 153 & 4.00 & 184 & 40.0 & 37.0 \\
$\mathrm{~V}$ & 2.00 & 1.00 & 2.00 & 6.00 & 2.00 & 70 & 2.00 & 3.00 \\
$\mathrm{Cr}$ & 5.00 & 5.00 & 4.00 & 37.0 & 2.00 & 173 & 3.00 & 6.00 \\
$\mathrm{Mn}$ & 18.0 & 10.0 & 15.0 & 51.0 & 4.0 & 183 & 16.0 & 21.0 \\
$\mathrm{Fe}$ & 455 & 312 & 350 & 1950 & 34.0 & 184 & 431 & 479 \\
$\mathrm{Ni}$ & 3.00 & 1.00 & 2.00 & 8.00 & 2.00 & 128 & 2.00 & 3.00 \\
$\mathrm{Cu}$ & 5.00 & 10.0 & 3.00 & 126 & 2.00 & 166 & 5.00 & 6.00 \\
$\mathrm{Zn}$ & 45.0 & 41.0 & 30.0 & 260 & 2.00 & 184 & 29.0 & 61.0 \\
$\mathrm{As}$ & 28.0 & 38.0 & 18.0 & 394 & 7.00 & 183 & 15.0 & 42.0 \\
$\mathrm{~Pb}$ & 11.0 & 9.00 & 8.00 & 53.0 & 5.00 & 87 & 5.00 & 12.0 \\
\hline
\end{tabular}

oppositely the soil source was decreased. The traffic source was higher in 2014 and during the next two years it was quite constant. The oil source was also relatively stable during the period of study.

\section{Concentration Weighted Trajectory Analysis}

The concentration weighted trajectory (CWT) is a type of statistical trajectory model and it is widely used to locate the regional source areas potentially affecting the receptor site by long-range transportation (Chandra et al., 2014). In this method, the mean concentration is calculated and used as weight for the residence time of the trajectory in each modeled grid cell and assigned equally to all segments of trajectory (Wang et al., 2009). Back trajectory calculations were done by HYSPLIT (Hybrid Single-Particle Lagrangian Integrated Trajectory) model using a global 

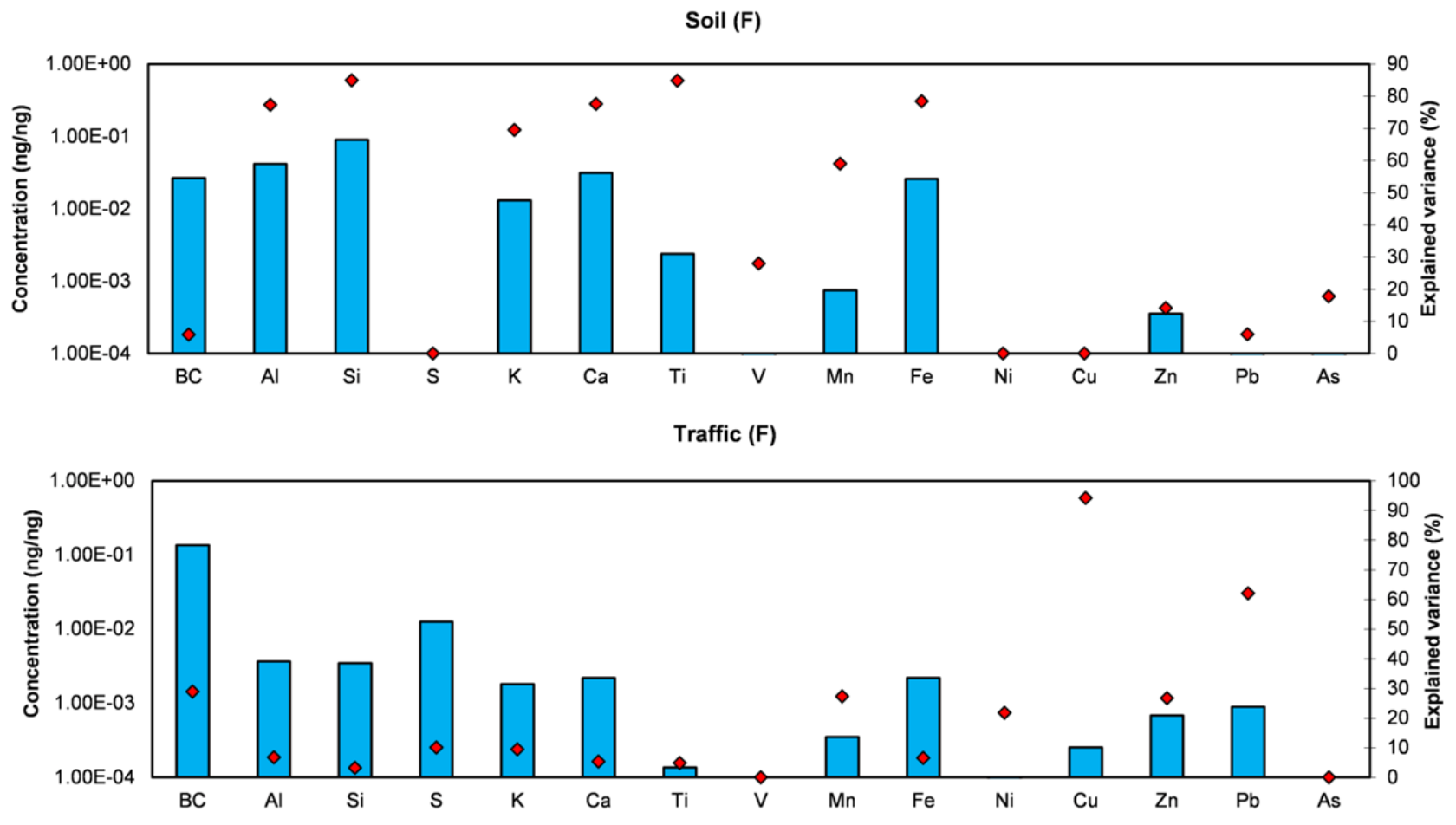

Coal combustion (F)
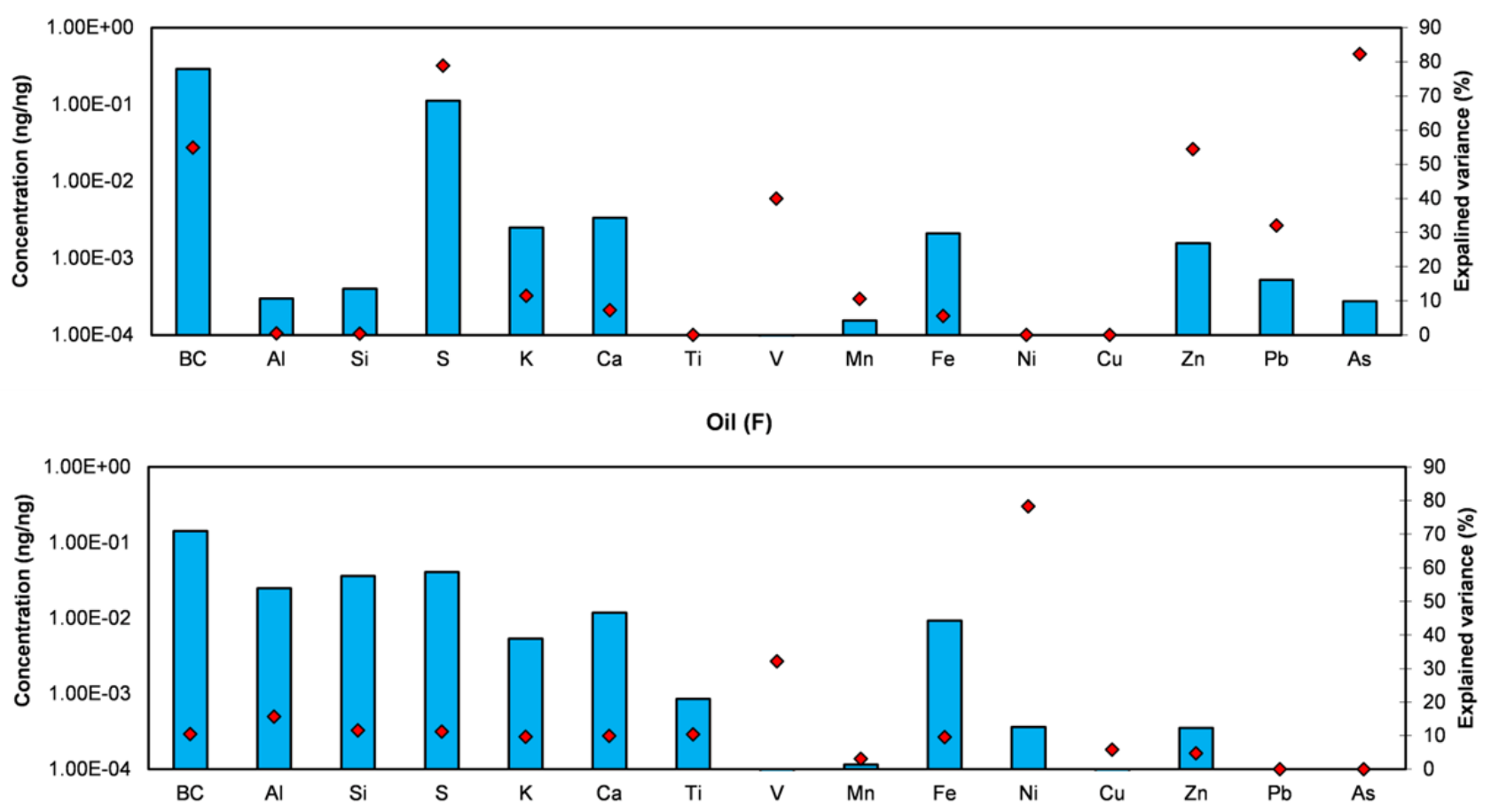

Fig. 6. Elemental source profiles derived by $\mathrm{PMF}$ for $\mathrm{PM}_{2.5}$ samples.

meteorological dataset GDAS. The trajectories were computed for an altitude of $1500 \mathrm{~m}$ above ground level and 120 hours backward for the sampling days. The height was selected to better represent long-range transport events. Otherwise, it may be affected by local sources and topography. For the CWTs, Zefir tool was used (Petit et al., 2016).

Fig. 8 shows air mass back trajectories of each source of
$\mathrm{PM}_{2.5}$ contributions. From the result of the CWT analyses, it seems clear that northwest and north part contributes dominantly to the sampling area. Due to the breakdown in Siberian high-pressure zone, wind originates usually from northwest direction to Ulaanbaatar (Davy et al., 2011). However, the combustion and traffic source trajectories indicate a more local behavior. The oil source seems affected from long-range transportation from northerly direction. 


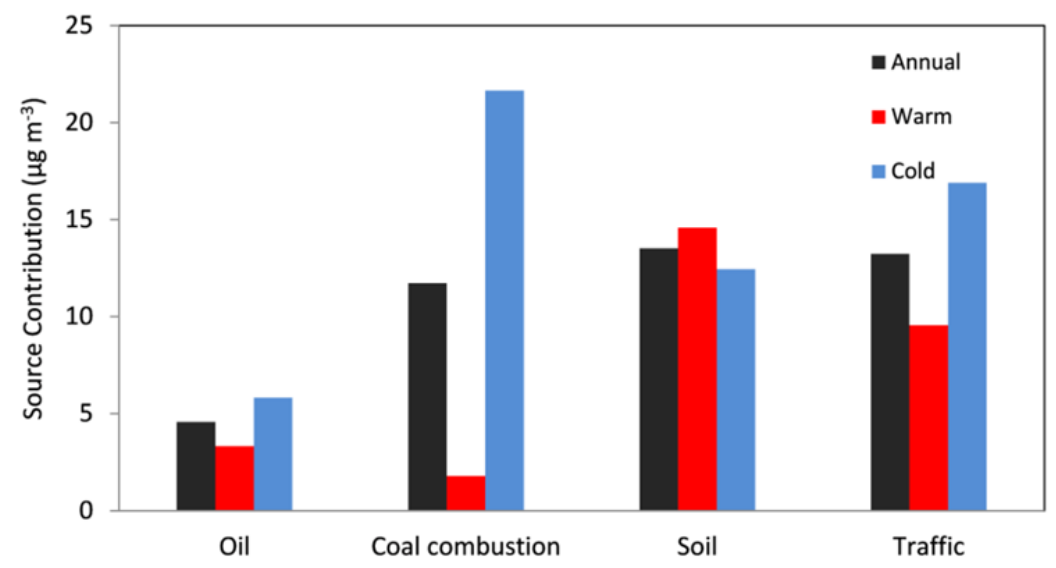

Fig. 7. Seasonal source mass contribution to $\mathrm{PM}_{2.5}$.

Table 5. Yearly source contributions to $\mathrm{PM}_{2.5}$ by average mass and percentage.

\begin{tabular}{|c|c|c|c|c|c|c|}
\hline \multirow{2}{*}{ Sources } & \multicolumn{2}{|l|}{2014} & \multicolumn{2}{|l|}{2015} & \multicolumn{2}{|l|}{2016} \\
\hline & Average $\left(\mu \mathrm{g} \mathrm{m}^{-3}\right)$ & $\%$ & Average $\left(\mu \mathrm{g} \mathrm{m}^{-3}\right)$ & $\%$ & Average $\left(\mu \mathrm{g} \mathrm{m}^{-3}\right)$ & $\%$ \\
\hline Soil & 12 & 31 & 16 & 40 & 14 & 28 \\
\hline Traffic & 14 & 36 & 11 & 28 & 14 & 29 \\
\hline Coal combustion & 8 & 21 & 8 & 19 & 17 & 34 \\
\hline Oil & 4 & 12 & 5 & 14 & 4 & 9 \\
\hline
\end{tabular}
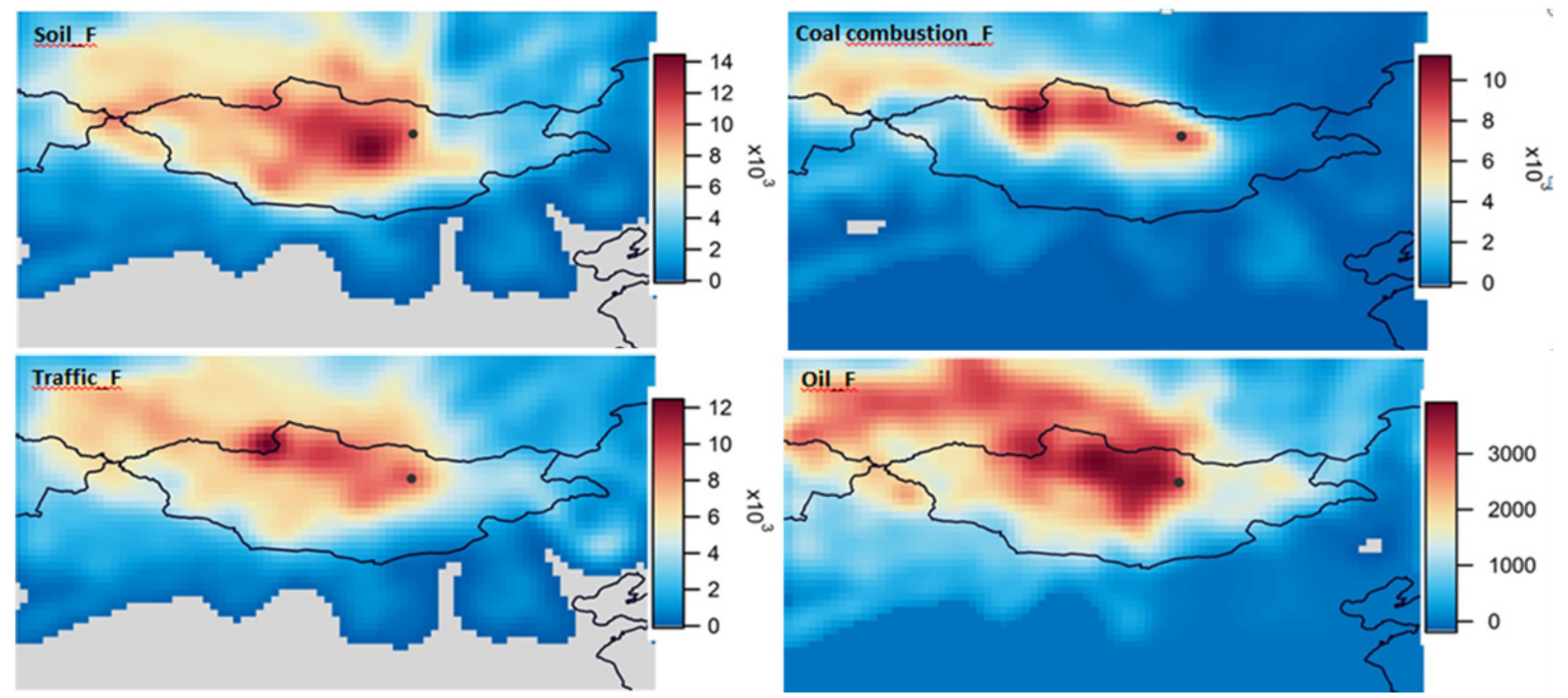

Fig. 8. CWT for the $\mathrm{PM}_{2.5}$ source contributions showing potential source locations (concentrations in $\mathrm{ng} \mathrm{m}^{-3}$ ).

\section{CONCLUSIONS}

This study, which was conducted in Ulaanbaatar, Mongolia, provides insight into APM related pollution in the area.

PM samples were chemically analyzed with a secondary target commercial ED-XRF system, which was found to be highly suitable for rapid quantitative analysis. The obtained MDL values demonstrate that determining low concentrations of an element on a filter is possible.

Applying the PMF statistical technique to these PM samples, the elemental source fingerprints and contributions to the total mass were identified. The results of the study indicate that coal combustion for domestic heating is a primary source; additionally, the air quality in the area is significantly affected by the scattering of dust formed in heating ovens. Coal dust is produced in high amounts and, in many cases, discarded directly onto the soil. Thus, the resuspended dust is a combination of natural and anthropogenic emissions. This finding is confirmed by the source profiles and the temporal variation in the source contributions, which indicate that fly ash originating in 
coal combustion is mixed with traffic emissions and resuspended soil. The following 4 sources were determined for both size fractions: soil, coal combustion, traffic and oil combustion. The respective contributions of these sources were $35 \%, 16 \%, 41 \%$ and $8 \%$ of the coarse fraction, whereas they were $31 \%, 27 \%, 31 \%$ and $11 \%$ of the fine fraction.

The mass contributions to the fine fraction show that combustion related sources dominate the cold season (October-March), whereas crustal matter sources dominate the warm season (April-September). In the coarse fraction, traffic (mixed with coal combustion) emissions dominate the cold season, whereas soil dominates the warm season.

Concentration-weighted trajectory analysis, which was applied to assess the influence of long-range transport on the sampling area, suggests that transported emissions primarily increase the contribution from heavy oil combustion.

Overall, this work highlights the importance of detailed air quality research in less studied areas. The differences in human habitat, environmental conditions and topography between the region we examined and other areas, such as Europe and North America, as well as other parts of Asia, create the opportunity to reevaluate the performance of well-known methods of environmental analysis.

\section{ACKNOWLEDGEMENTS}

This project was funded by Mongolian Foundation for Science and Technology and supported in part by the International Atomic Energy Agency (IAEA) through the Regional Cooperation Agreement Program "RAS/7/023."

Moreover, this work has been supported by the IAEA and the International Centre for Theoretical Physics and through an IAEA-ICTP Sandwich Training Educational Program fellowship C6/MON/15001 granted to Gerelmaa Gunchin.

\section{REFERENCES}

Calzolai, G., Chiari, M., Lucarelli, F., Mazzei, F., Nava, S., Prati, P., Valli, G. and Vecchi, R. (2008). PIXE and XRF analysis of particulate matter samples: An interlaboratory comparison. Nucl. Instrum. Methods Phys. Res., Sect. B 266: 2401-2404.

Chandra, S., Kulshrestha, M.J. and Singh, R. (2014). Temporal variation and concentration weighted trajectory analysis of lead in $\mathrm{PM}_{10}$ aerosols at a site in Central Delhi, India. Int. J. Earth Atmos. 2014: 323040.

Cohen, D.D., Garton, D., Stelcer, E., Hawas, O., Wang, T., Poon, S., Kim, J., Choi, B.C., Oh, S.N., Shin, H.J., Ko, M.Y. and Uematsu, M. (2004). Multielemental analysis and characterization of fine aerosols at several key ACE-Asia sites. J. Geophys. Res. 109: D19S12.

Cohen, D.D., Stelcer, E., Atanacio, A. and Crawford, J. (2014). The application of IBA techniques to air pollution source fingerprinting and source apportionment. Nucl. Instrum. Methods Phys. Res., Sect. B 318: 113-118.

Davy, P.K., Gunchin, G., Markwitz, A., Trompetter, W.J., Barry, B.J., Shagjjamba, D. and Lodoysamba, S. (2011). Air particulate matter pollution in Ulaanbaatar, Mongolia:
Determination of composition, source contributions and source locations. Atmos. Pollut. Res. 2: 126-137.

Diapouli, E., Manousakas, M., Vratolis, S., Vasilatou, V., Maggos, T., Saraga, D., Grigoratos, T., Argyropoulos, G., Voutsa, D., Samara, C. and Eleftheriadis, K. (2017). Evolution of air pollution source contributions over one decade, derived by $\mathrm{PM}_{10}$ and $\mathrm{PM}_{2.5}$ source apportionment in two metropolitan urban areas in Greece. Atmos. Environ. 164: 416-430.

Eleftheriadis, K. and Colbeck, I. (2001). Coarse atmospheric aerosol: Size distributions of trace elements. Atmos. Environ. 35: 5321-5330.

Gunchin, G., Sereeter, L., Dagva, S., Tsenddavaa, A., Davy, P.K., Markwitz, A. and Trompetter, W.J. (2012). Air particulate matter pollution in Ulaanbaatar city Mongolia. Int. J. PIXE 22: 165-171.

Gutknecht, W., Flanagan, J., McWilliams, A., Jayanty, R.K.M., Kellogg, R., Rice, J., Duda, P. and Sarver, R.H. (2010). Harmonization of uncertainties of X-ray fluorescence data for $\mathrm{PM}_{2.5}$ air filter analysis. J. Air Waste Manage. Assoc. 60: 184-194.

Guttikunda, S. (2007). World bank consultant report, Washington, DC, USA.

Hasenkopf, C.A., Veghte, D.P., Schill, G.P., Lodoysamba, S., Freedman, M.A. and Tolbert, M.A. (2016). Ice nucleation, shape, and composition of aerosol particles in one of the most polluted cities in the world: Ulaanbaatar, Mongolia. Atmos. Environ. 139: 222-229.

Lide, D.R. (1992). CRC handbook of chemistry and physics, CRC Press. Boca Raton, Florida.

Maenhaut, W., Francois, F. and Cafmeyer, J. (1993). The GENT stacked filter unit sampler for collection of atmospheric aerosols in two size fractions. Report No. NAHRES-19, International Atomic Energy Agency, Vienna, pp. 249-263.

Manousakas, M., Diapouli, E., Papaefthymiou, H., Migliori, A., Karydas, A.G., Padilla-Alvarez, R., Bogovac, M., Kaiser, R.B., Jaksic, M., Bogdanovic-Radovic, I. and Eleftheriadis, K. (2015). Source apportionment by PMF on elemental concentrations obtained by PIXE analysis of $\mathrm{PM}_{10}$ samples collected at the vicinity of lignite power plants and mines in Megalopolis, Greece. Nucl. Instrum. Methods Phys. Res., Sect. B 349: 114-124.

Manousakas, M., Papaefthymiou, H., Diapouli, E., Migliori, A., Karydas, A.G., Bogdanovic-Radovic, I. and Eleftheriadis, K. (2017). Assessment of $\mathrm{PM}_{2.5}$ sources and their corresponding level of uncertainty in a coastal urban area using EPA PMF 5.0 enhanced diagnostics. Sci. Total Environ. 574: 155-164.

Ostro, B., Tobias, A., Karanasiou, A., Samoli, E., Querol, X., Rodopoulou, S., Basagaña, X., Eleftheriadis, K., Diapouli, E., Vratolis, S., Jacquemin, B., Katsouyanni, K., Sunyer, J., Forastiere, F. and Stafoggia, M. (2015). The risks of acute exposure to black carbon in Southern Europe: Results from the MED-PARTICLES project. Occup. Environ Med. 72: 123-129.

Paatero, P. (1997). Least squares formulation of robust non-negative factor analysis. Chemom. Intell. Lab. Syst. 37: 23-35. 
Paatero, P. and Hopke, P.K. (2003). Discarding or downweighting high-noise variables in factor analytic models. Anal. Chim. Acta 490: 277-289.

Paatero, P., Hopke, P.K., Hoppenstock, J. and Eberly, S.I. (2003). Advanced Factor Analysis of Spatial Distributions of $\mathrm{PM}_{2.5}$ in the Eastern United States. Environ. Sci. Technol. 37: 2460-2476.

Petit, J.E., Favez, O., Albinet, A. and Canonaco, F. (2016). A user friendly tool for comprehensive evaluation of the geographical origins of atmospheric pollution: Wind and trajectory analyses. Environ. Modell. Software 88: 183187.

Prost, J., Zinkl, A., Ingerle, D., Wobrauschek, P. and Streli, C. (2018). Evaluation of a sample preparation procedure for total-reflection X-ray fluorescence analysis of directly collected airborne particulate matter samples. Spectrochim. Acta, Part B 147: 13-20.

Reff, A., Eberly, S.I. and Bhave, P.V. (2007). Receptor modeling of ambient particulate matter data using positive matrix factorization: Review of existing methods. J. Air Waste Manage. Assoc. 57: 146-154.

Santoso, M., Hopke, P.K., Hidayat, A. and Diah Dwiana, L. (2008). Sources identification of the atmospheric aerosol at urban and suburban sites in Indonesia by positive matrix factorization. Sci. Total Environ. 397: 229-237.

Sarigiannis, D.A., Handakas, E.J., Kermenidou, M., Zarkadas, I., Gotti, A., Charisiadis, P., Makris, K., Manousakas, M., Eleftheriadis, K. and Karakitsios, S.P. (2017). Monitoring of air pollution levels related to Charilaos Trikoupis Bridge. Sci. Total Environ. 609: 1451-1463.
Shaltout, A.A., Boman, J. and Alsulimane, M.E. (2017). Identification of elemental composition of $\mathrm{PM}_{2.5}$ collected in Makkah, Saudi Arabia, using EDXRF. X-Ray Spectrom. 46: 151-163.

Shaltout, A.A., Hassan, S.K., Karydas, A.G., Zaki, Z.I., Mostafa, N.Y., Kregsamer, P., Wobrauschek, P. and Streli, C. (2018). Comparative elemental analysis of fine particulate matter $\left(\mathrm{PM}_{2.5}\right)$ from industrial and residential areas in Greater Cairo-Egypt by means of a multisecondary target energy dispersive X-ray fluorescence spectrometer. Spectrochim. Acta, Part B 145: 29-35.

Ulaanbaatar City Governor'S Implementation Agency (2016). Ulaanbaatar statistical report. Department of Statistics, Ulaanbaatar City Governor's Implementation Agency, Mongolia.

Wang, Y.Q., Zhang, X.Y. and Draxler, R.R. (2009). TrajStat: GIS-based software that uses various trajectory statistical analysis methods to identify potential sources from long-term air pollution measurement data. Environ. Modell. Software 24: 938-939.

World Bank (2011). World bank report. Ulaanbaatar, Mongolia. World Bank, Washington, DC, USA.

World Health Organization (WHO) (2005). Air quality guidelines. Global update 2005. Particulate matter, ozone, nitrogen dioxide and sulfur dioxide. WHO Press, World Health Organization, Switzerland.

Received for review, September 25, 2018 Revised, January 8, 2019 Accepted, January 8, 2019 